11. Lasat M.M. Phytoextraction of toxic metals. A review of biological mechanisms // J. Environ. Quality. 2002. Vol. 31. P. $109-120$.

12. Галиулин Р.В., Галиулин Р.А., Кочуров Б.И. Фитоэкстракция почв и промышленных сточных вод, загрязненных тяжелыми металлами: концептуальная модель технологий фитоэкстракций, фито- и ризофильтрации // Экологические системы и приборы. 2004. № 2. С. 24-33.

13. Классификация и диагностика почв СССР. М.: Колос, 1977. $220 \mathrm{c}$.

14. Болдырев В.А., Пискунов В.В. Полевые исследования морфологических признаков почв: Учеб. пособие. Саратов: Изд-во Сарат. ун-та, 2006. 60 с.
15. Хазиев Ф.Х. Методы почвенной энзимологии. М.: Наука, 2005. 252 c.

16. Dick R.P. Soil enzyme activities as integrative indicators of soil health // Biological indicators of soil health / Eds. C.E. Pankhurst, B.M. Doube, V.V. Gupta. Wallingford: CABI Publ., 1997. P. 121-156.

17. Звягинцев Д.Г., Бабьева И.П., Зенова Г.М. Биология почв. 3-е изд., испр. и доп. М.: Изд-во Моск. ун-та, 2005. $448 \mathrm{c}$.

18. Квеситадзе Г.И., Хатисашвили Г.А., Садунишвили Т.А., Евстигнеева 3.Г. Метаболизм антропогенных токсикантов в высших растениях. М.: Наука, 2005. 199 с.

\title{
ГЕОЛОГО-ТЕКТОНИЧЕСКАЯ ИНТЕРПРЕТАЦИЯ ГРАВИМАГНИТНЫХ ДАННЫХ ПРИ ОТРАБОТКЕ РЕГИОНАЛЬНЫХ ГЕОФИЗИЧЕСКИХ ПРОФИЛЕЙ (на примере профиля “Уварово-Свободный»)
}

\section{М.И. Рыскин, Е.Н. Волкова, К.Б. Сокулина \\ Саратовский государственный университет, кафедра геофизики \\ E-mail: riskinmi@yandex.ru}

В статье рассматриваются результаты геологической интерпретации материалов, полученных при отработке регионального профиля «Уварово-Свободный» протяженностью 376 км. В процессе интерпретации использованы комплексные гравимагнитные построения. Выделены новые и подтверждены ранее известные тектонические элементы, уточнено положение разделяющих их границ.

Ключевые слова: аномалия, гравиразведка, магниторазведка, прогиб, антеклиза, грабен, геопотенциальное поле, комплексный параметр, кристаллический фундамент, максимум, минимум, плутон, региональный профиль.

\section{Geological-Tectonic Interpretation of Gravity-Magnetic Information in Development of Regional Geophysical Profiles (for Example: the Profile "Uvarovo-Svobodniy")}

\section{M.I. Ryskin, E.N. Volkova, K.B. Sokulina}

The article deals with the results of geological interpretation of geophysical data received during traversing («Uvarovo-Svobodny» line, the length is $376 \mathrm{~km}$ ). Integrated gravitomagnetic installations alongside were applied during the process of interpretation. The new tectonic elements were found, and previously found tectonic elements were confirmed. More accurate information about location of the border separating the mentioned tectonic elements was obtained.

Key words: anomaly, gravitational exploration, geomagnetic survey, flexure, anteclise, graben, geopotencial field, complex parameter, crystalline foundation, maximum, minimum, pluton, regional profile.

Основными положениями федеральных программ развития минерально-сырьевой базы Российской Федерации с 1994 года в качестве целевой задачи предусматривается создание государственной сети опорных геофизических профилей, параметрических и сверхглубоких скважин. В состав геофизических работ рекомендовано включать глубинные сейсмические и электромагнитные зондирования, а также аэромагнитные и гравиметрические исследования [1]. Однако последние проводились далеко не всегда. Между тем роль гравимагнитной информации в решении задач, которые ставятся при отработке подобных региональных профилей, весьма значительна, поскольку целеполагание их состоит в установлении основных закономерностей глубинного геологического строения нефтегазоносных бассейнов и горнорудных районов, а также в определении особенностей их тектоники. Известно, что эти закономерности и особенности обусловлены, прежде всего, вертикально-блоковой структурой кристаллического фундамента, а вертикально-блоковые модели лучше всего поддаются изучению именно геопотенциальными методами. При этом в поле силы тяжести более адекватное отображение находит рельеф поверхности фундамента, т.е. выступы (горсты) и впадины (грабены), тогда как магнитное поле более чувствительно к неоднородностям его внутренней структуры. В обоих полях четко проявляют себя линейными градиентными сгущениями изолиний глубинные разломы. В то же время выявление таких элементов геологического строения в волновом поле и на кривых электрозондирований представляет собой довольно сложную проблему. В работе [2], посвященной проблемам комплексной интерпретации геофизических данных по региональным профилям, отмечается, что гра- 
виразведку и аэромагниторазведку необходимо проводить по площади в полосе до 50 км на всей протяженности регионального профиля, так как профильная кривая интегрирует суммарное влияние всех петроплотностных и петромагнитных неоднородностей в трехмерном пространстве, а не только тех, что расположены в вертикальной плоскости профиля. Тем не менее на практике нередко ограничиваются проведением сугубо профильных наблюдений.

В предлагаемой статье рассматриваются эти и иные гравимагнитные аспекты проведения комплексных геофизических исследований по линии регионального профиля «Уварово-Свободный» длиной 360 км и трем субмердиональным рассечкам (290 км), проложенным на территории Саратовской области в малоизученной зоне сочленения Воронежской антеклизы с Рязано-Саратовским прогибом с целью уточнения модели геологического строения, оценки ресурсного потенциала и повышения лицензионной привлекательности нераспределенного фонда недр.

\section{О методике исследований}

Профильные высокоточные гравиметрические полевые работы осуществлены двумя приборами ГНУ-К2 с инструментальной погрешностью 0,03-0,05 мГал, с применением опорной сети, производством контрольных измерений в объеме $10 \%$ от общей протяженности профилей и с расстоянием между точками наблюдений 200 м. Профильные высокоточные магнитометрические полевые работы проведены двумя магнитометрами ММП-203 с расстоянием между точками 25 м. Осуществлены также все необходимые топографо-геодезические (нивелировочные) работы. Полевые гравимагнитные исследования и интерпретация полученных данных выполнены коллективом сотрудников и студентов кафедры геофизики Саратовского госуниверситета им. Н.Г. Чернышевского в 2006-2008 гг.

Главная особенность интерпретационного этапа состояла в увязке профильных данных с фондовыми материалами гравимагнитных съемок прошлых лет. Такая увязка и совместный анализ этих разнородных данных потребовались для того, чтобы компенсировать упомянутую ущербность профильной системы наблюдений и выявить пространственные закономерности распределения потенциальных полей, без чего невозможно достижение поставленных целей по уточнению модели геологического строения вышеназванной зоны сочленения двух крупных тектонических элементов Восточно-Европейской платформы.

Методика комплексной интерпретации гравимагнитных данных заключалась в проведении следующих операций:

1) анализ общей структуры геопотенциальных полей в двумерном (профильные кривые) и в трехмерном пространстве (карты $\Delta g_{a}{ }^{\text {Б }}$ и $\Delta T_{a}$ ), их сопоставление и увязка;

2) анализ геологической природы аномалий на кривых $\Delta g$ и $\Delta T$ с привлечением нижеследующих преобразований:

- выявление пространственных закономерностей распределения аномалий $\Delta g$ и $\Delta T$ на основе вычисления карт их корреляции и направленного суммирования;

- выявление пространственных закономерностей локализации аномалий $\Delta g$ и $\Delta T$ на основе вычисления карт $\Delta g_{\text {ост }}$ и $\Delta T_{\text {ост}}$, карт градиентов Саксова-Нигарда, карт стандартов (возмущенности) полей $\Delta g$ и $\Delta T$;

- решение двумерной обратной задачи грави- и магниторазведки по профильным кривым $\Delta g$ и $\Delta T$.

Теоретические основы и геологическое содержание этих операций хорошо известны из литературных источников, в том числе из публикаций исполнителей. Математическое обеспечение интерпретационных процедур составили:

- комплекс программ «TRANS», разработанный исполнителями на кафедре геофизики СГУ им. Н.Г. Чернышевского (2005 г.);

- программный комплекс «KOSKAD» (А.А. Никитин и А.В. Петров, МГГА им. Орджоникидзе, 2005 г.).

\section{Структура геофизических полей $\Delta g$ и $\Delta T$ и анализ их знаковых и пространственных соотношений по результатам ранее выполненных площадных съемок}

Профиль «Уварово-Свободный» проходит по территории северо-западной части Саратовской области через Рязано-Саратовский прогиб и зону его сопряжения с Воронежской антеклизой. Рязано-Саратовский прогиб находит очень заметное отображение в магнитном поле: четко видны характерные для этого структурного элемента северо-западные простирания и осевая часть, видимо, отвечающая древнему Пачелмскому авлакогену, где значения $\Delta T$ достигают местами 150 нТл, а возмущенность поля, оцениваемая величиной его стандарта (среднеквадратического отклонения) повышается до 5 нТл (рис. 1). Термин «авлакоген» (рифтогенный прогиб рифейского возраста) применительно к Пачелмскому прогибу был введен еще в 1955 году Н.С. Шатским.

В современном понимании [3] это узкая, линейно вытянутая на сотни километров рифтогенная система, состоящая из ступенчато погружающихся к осевому грабену блоков фундамента, ограниченная бортовыми разломами. Западный борт, осевая линия (зона рифта) и восточный борт авлакогена трассируются узкими линейно вытянутыми градиентными сгущениями изолиний, к двум первым из них в современном структурном плане примыкают Ртищевско-Баландинская (РБ) 


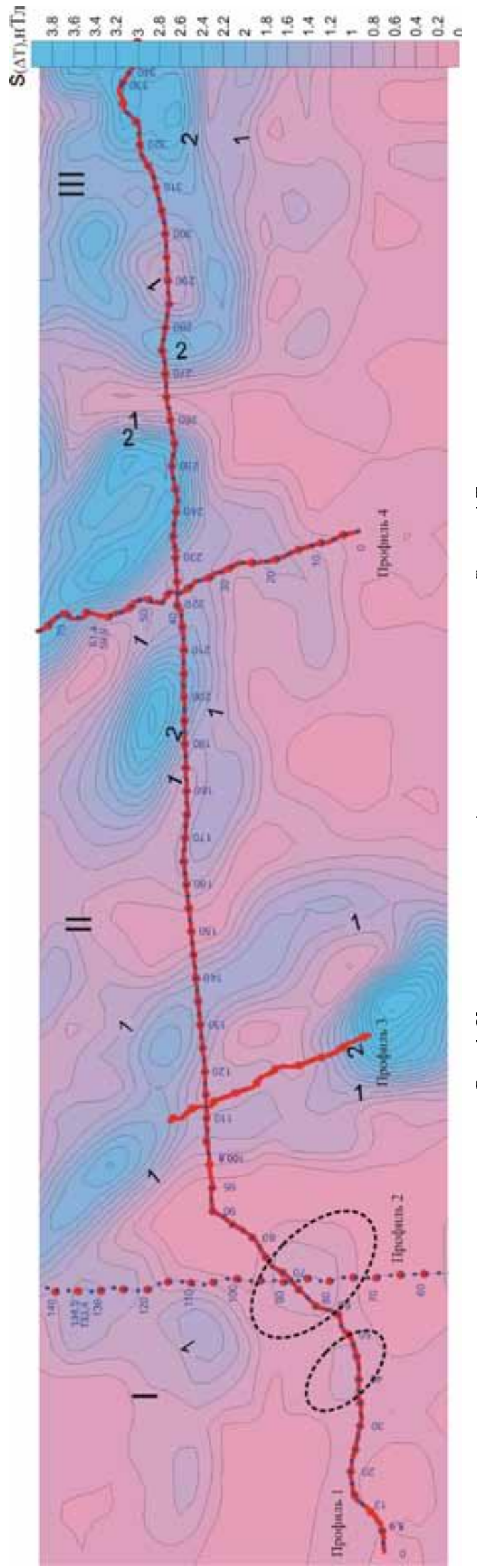

и Петровская (П) дислокации соответственно. С этими элементами сопрягаются зоны минимумов, где значения $\Delta T$ уменьшаются до 60 нТл. Область пониженных значений $\Delta T$ (от 60 до 75 нТл) к западу от борта отвечает согласно [3] восточным склонам Воронежской антеклизы. К востоку от осевой линии следует область максимумов, соотносимая в своей южной резко градиентной линейной оторочке с Базарно-Карабулакской (БК) дислокацией северо-восточного простирания; восточное окончание профиля находится в зоне высокоинтенсивной ( 150нТл) Неверкинской (Н) аномалии, отделенной от Карабулакской линейным минимумом того же Пачелмского простирания. Таким образом, по магнитному полю территория, где проходит профиль «Уварово-Свободный», традиционно районируется на 3 части: Западную (I) с относительно спокойным с пониженной напряженностью полем (Воронежская антеклиза), сложную центральную (II) с интенсивным сильно возмущенным полем в зоне, отвечающей Пачелмскому авлакогену, и восточную (III) с менее интенсивным полем.

Сходным образом районируется территория и по полю силы тяжести. Здесь выделяются те же области, но центральная часть отличается пониженными значениями $\Delta g$ (на уровне первых единиц мГал, а к северу и к югу от линии профиля значения $\Delta g$ становятся отрицательными). Иными словами, знаковое соответствие геопотенциальных полей в западной части прямое, а в центре инверсное. Однако по интенсивности наблюдается несколько иное соотношение: в области Воронежской антеклизы значения $\Delta T$, так же как и $\Delta g$, нарастают по мере движения с запада на восток. Это нарастание, хорошо видное по профильным кривым, идет до ПК $110(\Delta g)$ и 150( $\Delta T)$. Далее по обоим полям характер изменчивости близок к пилообразному, а в региональном плане намечается протяженный, но слабоконтрастный минимум, причем и по кривой $\Delta T$ (с ПК 200 до $280)$, и по кривой $\Delta g$ (с ПК 140 до ПК 320) этот минимум вырисовывается в области еще более низкочастотного максимума. Далее на восток с ПК 300 значения $\Delta g$ в целом нарастают, а по кривой $\Delta T$ общий уровень поля сохраняется, как и пилообразный характер его изменчивости. Таким образом, в целом фиксируется картина, четко отображаемая на карте распределения значений коэффициента корреляции полей $\Delta g$ и $\Delta T$ (рис. 2).

Область I имеет знакопеременный характер, тогда как область II занята преимущественно участками положительной корреляции $\Delta g$ и $\Delta T$, a восточный участок III - отрицательной.

Картина, выявляемая при анализе распределения коэффициентов корреляции, дополняется и уточняется по картам направленного суммирования геопотенциальных полей, предварительно отнормированных и тем самым лишенных размерности. С помощью направленного суммирования удается провести оригинальные комплексные по- 
строения, позволяющие лучше определить черты общности и различия в структуре этих полей, установить геологическую природу аномалий. Идея и технология таких построений разработаны на кафедре геофизики Саратовского университета, освещены в ряде публикаций [4 и др.]. Примером подобного построения может служить карта гравимагнитного комплексного параметра (КП) (карта «сходства»), представленная на рис. 3 .

На первый взгляд, на этой карте отображаются те же пространственные закономерности соотношения обоих геопотенциальных полей: четкое разделение на области с разным характером $\Delta g$ и $\Delta T$ по всем признакам (знаку, интенсивности, изменчивости, ориентировке изолиний и пр.). Все это свидетельствует о единой (в региональном плане) геологической природе аномалий $\Delta g$ и $\Delta T$, об их обусловленности общими геологическими источниками, которыми являются рельеф поверхности кристаллического фундамента и неоднородность его внутренней структуры. Наиболее вероятный вариант трактовки этой геологической природы состоит в следующем.

В области Воронежской антеклизы с изометричными очертаниями аномалий, где фундамент наиболее приподнят и сложен петрофизическим комплексом с общей низкой (ниже 1,25 A/м) намагниченностью пород и довольно значительной изменчивостью эффективной плотности. По мнению авторов [5], эти свойства комплекса аналогичны таковым для нижнепротерозойской Воронцовской серии, характерной для Воронцовской зоны Воронежского массива. Воронцовская серия сложена неравномерно метаморфизованными метатерригенными породами - различного рода сланцами и метапесчаниками (местами переходящими в гнейсы) часто в различном переслаивании, с прослоями метабазальтов и метаандезитов. Такая трактовка по [5] подтверждается данными бурения. В целом область распространения воронцовской серии характеризуется положительными магнитными аномалиями с уровнем 150-50 нТл (как это видно на картах $\Delta T$ ) и занимает все пространство от южного борта Рязано-Саратовского прогиба вплоть до района г. Волгограда.

Однако более внимательное рассмотрение области I на карте (см. рис. 3) свидетельствует о том, что она неоднородна и разделяется в интервале пикетов (ПК) 40-60 на две части: западную и восточную, разграниченные градиентной зоной характерного Пачелмского простирания (с северо-запада на юго-восток). Восточная часть характеризуется более высокими значениями КП и наличием в ее пределах локальных максимумов округлой формы. Два таких максимума, отмеченные пунктирным контуром (см. рис. 3) фиксируются непосредственно на линии регионального профиля. Заметны эти объекты и на карте рис. 1. Какова их природа?

В работе [5, с. 59] указывается, что «в кровле фундамента местами обособляются объекты 


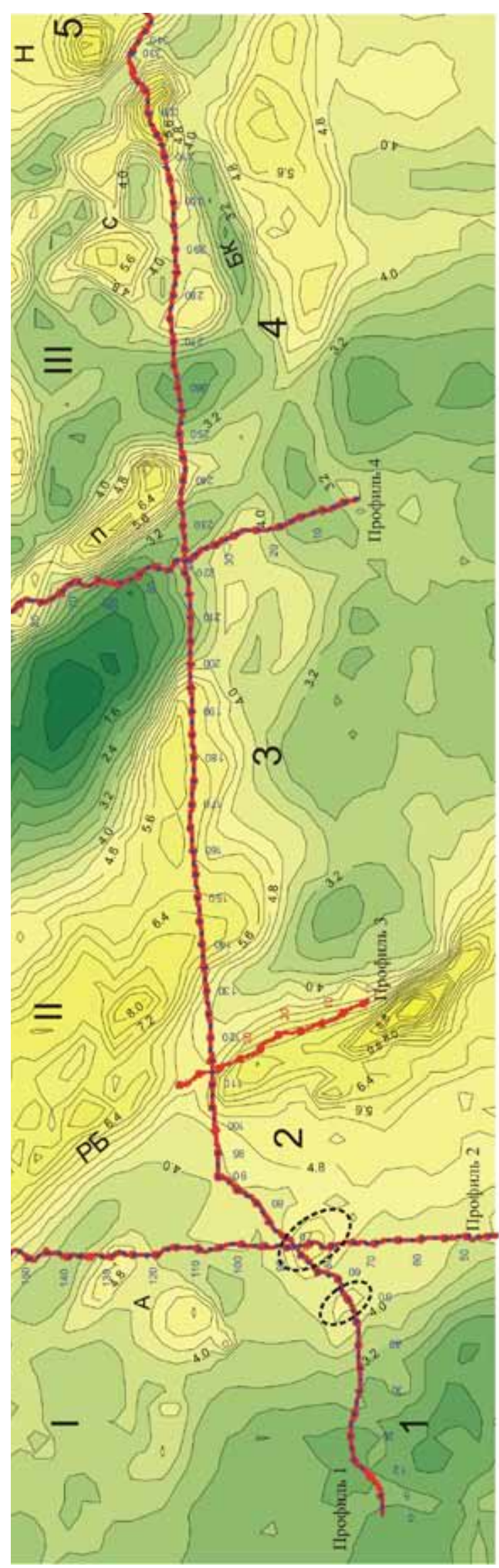

округлой формы с поперечником около 20-30 км, сложенные породами относительно высокой (свыше $2,73-2,74 \cdot 10^{3} \kappa г / \mathrm{M}^{3}$ ) плотности и повышенной намагниченности». По-видимому, именно этим объектам (часто с концентрической внутренней структурой) отвечают упомянутые аномалии, обусловленные многофазными гипербазитбазитовыми плутонами еланского комплекса с рудоносными норит-диоритовыми телами, однако бурением такие тела не вскрыты [5].

Рассматриваемая восточная часть ассоциируется с Аркадакским (А) прогибом, который обычно относят к Воронежской антеклизе [3]. Однако существенно иная структура потенциальных полей, выявляемая по карте КП (общее увеличение значений комплексного параметра, преимущественно линейный рисунок поля, характерная северо-западная ориентировка изолиний, отмеченные проявления активной магматической деятельности - наличие плутонов), заставляет предположить, что восточнее пикета 40 происходит резкое погружение фундамента. Собственно здесь, по-видимому, и начинается Рязано-Саратовский прогиб. Весьма выразительно указанные различия проявляются и на трансформированных (пересчитанных на глубину 3000 м) кривых $\Delta g$ и $\Delta T$, а также на разрезе соответствующих эффективных плотностей (рис. 4). Таким образом, Аркадакский прогиб следует включить в ареал Рязано-Саратовского прогиба и констатировать, что восточная граница Воронежской антеклизы проходит значительно западнее, чем предполагалось до проведения настоящих исследований (на прежних тектонических схемах эта граница проецировалась в районе ПК 120, т.е. на 80 км восточнее). Прояснить ситуацию может обращение к профилю 2, который пересекает основной региональный профиль «Уварово-Свободный» в районе ПК 70 и по представлениям, существовавшим до проведения настоящих работ, практически целиком расположен в пределах Воронежской антеклизы. Однако полученные комплексные геофизические данные показали, что в пределах профиля наблюдается (в сравнении с Воронежской антеклизой) синхронное однознаковое увеличение значений $\Delta T$ и особенно $\Delta g$. Иными словами можно предположить, что этот профиль проходит по склоновой части Аркадакского прогиба, примыкающего к Воронежской антеклизе с востока. По карте КП этот профиль также тяготеет к «переходной» зоне от Воронежской антеклизы к Рязано-Саратовскому прогибу. Нельзя не отметить, что данный вывод полностью согласуется с мнением специалистов Нижне-Волжского НИИ геологии и геофизики (НВ НИИ ГГ), занимавшихся обработкой материалов сейсмо- и электроразведки.

Центральная область II отделена от Аркадакского прогиба (см. рис. 3) интенсивной зоной высоких градиентов КП (интервал ПК 110-130), отвечающих Баландинско-Ртищевскому грабену, 


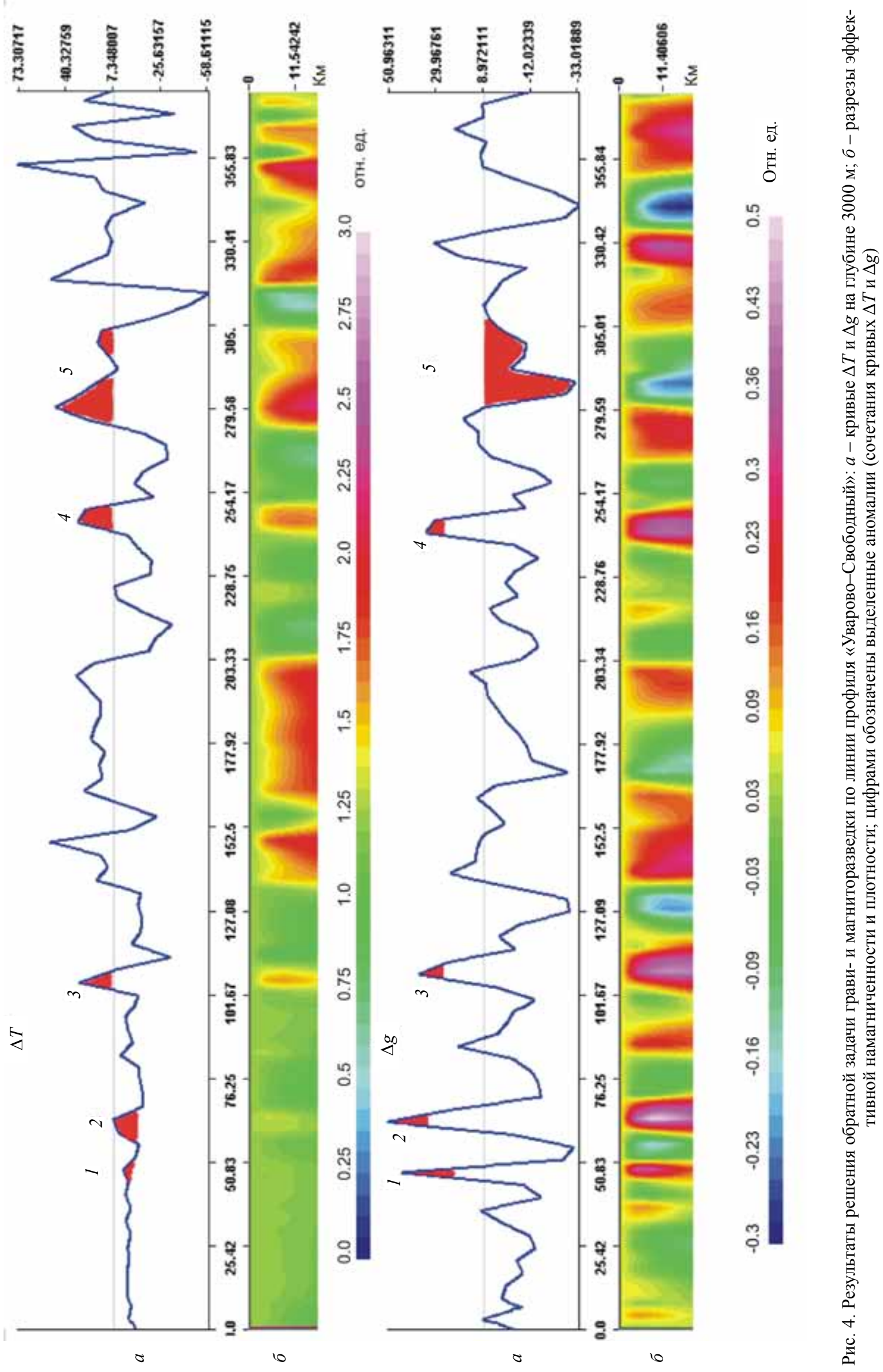


четко выраженному во всех геофизических полях. Подобная высокоинтенсивная зона на ПК 240-260 разделяет области II и III. Наконец, последняя полоса повышенных градиентов северо-западного простирания фиксируется на карте в интервале ПК 325-330 (см. рис. 3).

Петрофизический комплекс фундамента в областях II и III сложен по [5] средненамагниченными (от 1,3 до 2,5 A/м) образованиями со средней плотностью $\sim 2,71-2,75 \cdot 10^{3}$. Такие петрофизические особенности характерны для метаосадочных и метавулканических образований среднего состава. Еще далее к востоку уходя в пределы Прикаспийской впадины, распространен петрофизический комплекс, сложенный высоконамагниченными породами (2,5-3,8 А/м), отличающимися относительно невысокой плотностью $\left(<2,71 \cdot 10^{3}\right.$ кг $\left./ \mathrm{m}^{3}\right)$. Он по [5] представляет собой преимущественно метавулканические образования основного состава зеленокаменной фации метаморфизма.

Границы распространения этих комплексов - блоков фундамента имеют разрывной характер и контролируются глубинными разломами в виде упомянутых линейных градиентных зон на карте (см. рис. 3).

Обширный сегмент II, отвечающий области Рязано-Саратовского прогиба, как уже говорилось, отличается высоким уровнем значений КП, т.е. здесь (до ПК 200) наблюдается согласованное поведение геофизических полей. Область III отмечена относительно низкими величинми КП, т.е. слабым пространственным соответствием $\Delta g$ и $\Delta T$. В целом вся восточная часть территории выглядит в рисунке поля КП весьма неоднородно: ей отвечает неустойчивая знакопеременная картина.

\section{Соотношение профильных кривых $\Delta g$ и $\Delta T$}

Обратимся далее к анализу соотношения кривых $\Delta g$ и $\Delta T$ непосредственно по линии регионального профиля «Уварово-Свободный». Такой анализ целесообразно вести в сопоставлении с результатами преобразований геопотенциальных полей, осуществленных с целью локализации аномалий (объектов поиска).

В начальной части профиля наблюдается относительно малоизменчивое поведение кривой $\Delta T$ и более вариативное, волнообразно- колебательное, кривой $\Delta g$. В целом в этой части регистрируется два упомянутых локальных максимума $\Delta g$ : первый - с амплитудой до 5 мГал (на ПК 50) и второй с амплитудой более 5 мГал (на ПК 65). По кривой $\Delta T$ лучше виден второй. Первый, хотя и слабо проявился в рельефе кривой, но хорошо заметен на карте $\Delta T$. Его эпицентр находится несколько севернее гравитационного, но совершенно очевидно, что эти экстремумы обусловлены одними и теми же источниками в обоих полях - упоминавшимися плутонами Еланского комплекса. Смещение магнитных аномалий отно- сительно гравитационных обусловлено, очевидно, невертикальной намагниченностью этих тел. Локальные максимумы 1 и 2 особенно четко проявляются в трансформациях геопотенциальных полей: на графиках и картах остаточных аномалий (после осреднения и вычитания региональной низкочастотной компоненты поля) и на картах градиентов обоих полей. На картах градиентов Саксова-Нигарда с малыми радиусами осреднений (0,5-1 км) максимумы 1 и 2 фигурируют как самостоятельные, вполне обособленные аномалии, но с увеличением этих радиусов происходит их постепенное «сращивание» в единое телоисточник. Тем не менее на вертикальных картах плотностей и намагниченностей (рис. 4), полученных решением обратной задачи грави- и магниторазведки с использованием комплекса «KOSKAD», такого объединения не отмечается: видно, что тела-источники существуют обособленно, это подтверждает правомерность трактовки их геологической природы как гипербазит-базитовых плутонов. На картах полных градиентов поля $\Delta g$ наиболее интересным результатом, помимо локализации рассматриваемых аномалий, является трассировка разрывных нарушений в виде линеаментов различной протяженности.

От ПК 70 и далее на восток выдерживается более или менее синхронный характер нарастания значений $\Delta g$ и $\Delta T$, которое прослеживается вплоть до ПК 110 км. Здесь же отмечается самая высокая точка - крупный максимум $\Delta g$ и $\Delta T$. Судя по рисунку обоих полей, в этом месте фиксируется крупная неоднородность структуры фундамента, обособленность которой лучше всего выявляется в магнитном поле. В поле $\Delta g$ и его производных подобная аномалия приобретает линейно вытянутую форму, что позволяет ассоциировать ее с мощной разломной зоной повышенной плотности, обусловленной, по всей вероятности, воздействием изверженных пород (диоритов и т.п.), образующих пластовые интрузии в теле фундамента или магнитоактивных метаморфических пород (возможно, магнетитовых и амфиболитовых сланцев упоминавшейся Воронцовской серии). Так полагает Б.А. Андреев [6], который отмечает, что в пределах Восточно-Европейской платформы такое соответствие непосредственно подтверждено результатами глубокого бурения и что аномалии, связанные с магматическими породами, приуроченными к разломам, встречаются в большинстве случаев значительно реже, чем аномалии, вызванные метаморфическими породами.

В интервале ПК 110-130, где в обоих полях фиксируется сопряженная минимаксная аномалия 3 (см. рис. 4), проявляет себя РтищевскоБаландинская дислокация, которую можно соотнести с Западным бортом древнего Пачелмского авлакогена. Борт четко отмечается максимумом возмущенности $S$ (см. рис. 1), узкой зоной знаковой инверсии $\Delta g$ и $\Delta T$ (см. рис. 2), интенсивными аномалиями градиентов и остаточных аномалий. 
Все эти аномалии имеют характер разрывных линеаментов, что свидетельствует об очевидной дизъюнктивной природе упомянутого бортового сооружения.

С пикета 130 до ПК 150 прослеживается участок прямого соотношения $\Delta g$ и $\Delta T$, за которым следует до ПК 200 область более или менее постоянного уровня кривой $\Delta T$. В поле $\Delta g$ здесь фиксируется, как уже говорилось, область пониженных значений, а в поле $\Delta T$, напротив, прослеживается область повышенных значений. Судя по характеру распределения эффективных плотностей на рис. 4, этот интервал профиля пространственно отвечает Аткарскому палеовыступу фундамента. Палеовыступу в современном структурном плане соответствует инверсионная впадина, а следовательно, и разрастание толщин осадочных образований, в связи с чем частично понижается уровень значений поля $\Delta g$.

В районе ПК 245-250 отмечается интенсивный локальный максимум значений $\Delta g$ и $\Delta T$ (см. рис. 4, аномалия 4), по которому, очевидно, проходит осевая линия Рязано-Саратовского авлакогена - узкая рифтовая «щель» с характерными особенностями вертикально-блокового изменения геометрии границ и физических свойств пород по латерали (уплотнение и повышение намагниченности). На картах площадных трансформаций геопотенциальных полей эта узкая зона выражена четкими протяженными «разрывными» линеаментами. Локальный максимум осложняет конгруэнтную по обеим кривым широкую зону минимума (ПК 200-270). В современном структурном плане данная зона соответствует Чембарско-Петровскому грабену.

К востоку от указанного максимума по профилю «Уварово-Свободный» наблюдается плавный волнообразный характер изменчивости значений $\Delta g$ при общей тенденции к возрастанию. Характер вариаций магнитного поля более изрезанный, причем в интервале ПК 270-310, т.е. уже в пределах ранее выделенной области III, наблюдается инверсный характер сочетания кривых $\Delta g$ и $\Delta T$ (см. рис. 4, аномалия 5). Характер инверсии полей $\Delta g$ и $\Delta T$ здесь весьма своеобразный и не часто встречающийся - максимуму $\Delta T$ отвечает достаточно глубокий минимум $\Delta g$. Подобная картина наблюдается тогда, когда неоднородность - источник аномалий - сложена породами с небольшой плотностью и повышенной намагниченностью. Обычно такой феномен объясняют либо серпентинизацией кристаллических пород фундамента, либо внедрением в его толщу интрузий сиенитов. И серпентиниты, и сиениты характеризуются относительно невысокой плотностью (до

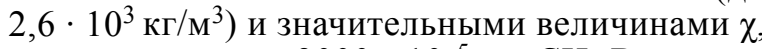
превосходящими $3000 \cdot 10^{-5}$ ед. СИ. В данном случае следует отдать предпочтение сиенитовой трактовке обсуждаемого сочетания $\Delta g$ и $\Delta T$, поскольку из близлежащих Гусихинских скважин в интервале фундамента были подняты образцы керна с сиенитом.

Еще далее в интервале ПК 327-350 обращает на себя внимание наличие (на фоне минимаксного участка кривой $\Delta g$ ) сопряженной области минимальных значений $\Delta T$. На картах геопотенциальных полей и их трансформаций здесь рисуется последняя из ранее упомянутых интенсивная линейная градиентная зона. Ее обычно идентифицируют с восточной границей (бортом) авлакогена, а весь рассмотренный участок от максимумов ПК 270-310 и до этой границы с Сосновской (C) депрессией в составе Рязано-Саратовского мегапрогиба. Однако по результатам анализа полученных данных сейсмо- и электроразведки специалисты НВ НИИ ГГ «отнесли» этот участок к Самарскому блоку Жигулевско-Пугачевского свода Волго-Уральской антеклизы, а самый последний фрагмент регионального профиля от ПК 330 до ПК 376 отождествили с локальным выступом фундамента на западном окончании Пугачевского свода Волго-Уральской антеклизы (возможно, Терешкинской вершиной). Выступ имеет свое четкое отображение в потенциальных полях, как исходных, так и трансформированных. Он прорисован на карте рис. 3 локальным максимумом КП изометричных очертаний у восточного среза карты, на карте рис. 1 максимумом возмущенности поля $\Delta T$, на карте рис. 2 «ярким пятном» плюсовых значений коэффициента корреляции $\Delta g$ и $\Delta T$ в отрицательном поле. Таким образом, и все эти особенности, и существенная изменчивость характера кривых и разрезов на рис. 4 не противоречат выводам сейсмо- и электроразведчиков [7].

Рассмотренное выше соотношение профильных кривых $\Delta g$ и $\Delta T$ дает основание выделить целый ряд аномалий с определенными знаковыми сочетаниями. Впервые такие сочетания были истолкованы Э.Э. Фотиади. Он рассмотрел четыре основных знаковых сочетания: два прямых (максимум $\Delta g$ - максимум $\Delta T$ и минимум $\Delta g-$ минимум $\Delta T$ ) и два инверсных (максимум $\Delta g-$ минимум $\Delta T$ и минимум $\Delta g-$ максимум $\Delta T)$. Будем обозначать их соответственно «++», «--», «+-», «-+». Позднее появились работы, в которых рассмотрены и так называемые сложные сочетания (В.В. Семеркин, Н.Я. Кунин и др.). Причем, Н.Я. Кунин довел число сочетаний до 36. Для толкования геологической природы сочетаний этими авторами использованы разнообразные геологические источники, включая данные бурения. Учитывая характер задач, поставленных перед работами по региональному профилю, на рис. 4 цифрами обозначены очевидные простые сочетания, когда к единичному максимуму (минимуму) в рельефе одной кривой соответствует также единичный экстремум другой. Эти сочетания охарактеризованы в нижеприведенной таблице. 
Геологическая природа некоторых знаковых сочетаний $\Delta g$ и $\Delta T$

\begin{tabular}{|c|c|c|c|}
\hline Номер сочетания & ПК & Тип сочетания & Предполагаемая геологическая природа \\
\hline 1 & ПК 50 & ++ & Глубинный интрузив (плутон) \\
\hline 2 & ПК $65-70$ & ++ & Глубинный интрузив (плутон) \\
\hline 3 & ПК110-130 & ++ & Ртищевско-Баландинская разломная зона \\
\hline 4 & ПК245-250 & ++ & Осевая линия авлакогена (рифтовой зоны) \\
\hline 5 & ПК270 -310 & -+ & Сиенитовая интрузия \\
\hline
\end{tabular}

Природа сочетаний на ПК 50 и 65 уже неоднократно диагностировалась как глубинная, интрузивная (плутон). Малоамплитудные максимумы $\Delta g$ и $\Delta T$ в интервале ПК 70-90 не обнаруживаются на картах съемки $1: 200000$. По кривым на вертикальных картах рис. 4 можно предположить, что вещество на уровне глубин 3000 м характеризуется существенно повышенной плотностью при незначительном увеличении намагниченности.

Аномалия, отмеченная цифрой 3 в составе сложного интервала (ПК 110-130), связывалась нами с Ртищевско-Баландинской разломной зоной (и интрузией в толще фундамента). Характерно, что к северу от линии профиля эта линейная аномалия почти не прослеживается в поле $\Delta g$, а в поле $\Delta T$ приобретает «трассирующий» характер. По совокупности всех отмеченных особенностей, свойственных ей, можно предположить, что шовное сочленение отягощено интрузивными внедрениями в области, примыкающей к профилю с юга.

Далее следует не помеченное цифрами сложное сочетание рельефа кривых $\Delta g$ и $\Delta T$ (ПК 130170). На первый взгляд рисунок кривых $\Delta g$ и $\Delta T$ здесь существенно различается (см. рис. 4 ). По $\Delta T$ прежде всего видна сопряженная зона максимум - минимум, отороченная с обеих сторон небольшими максимумами. По $\Delta g$, наоборот, наиболее рельефно проступают краевые максимумы, а между ними можно разглядеть сильно редуцированную в области максимума зону сопряжения. На разрезе эквивалентных масс (см. рис. 4) сходство в указанной зоне более очевидно, хотя контрастность области минимума $\Delta T$ заметно выше, чем по $\Delta g$. Характерно, что по $\Delta g$ весь выделенный интервал на вертикальном разрезе рисуется как монолитный, но по $\Delta T$ это часть «массива», простирающегося далее на восток до ПК 200. В протяженном интервале ПК 150-200 по глубинным кривым и разрезам (см. рис. 4) рисуется наличие масс сильно магнитных и с пониженной плотностью, а с ПК 185 и далее до ПК 200 повышается и плотность. Весь рассмотренный интервал соответствует упоминавшейся крупной инверсионной структуре: Аткарский выступ (горст по фундаменту) - Аткарская впадина (разрастание толщин легких, преимущественно терригенных напластований).
Совокупность рассмотренных данных выявляет сложную структуру Рязано-Саратовского прогиба, для уяснения которой потребуется осуществить физико-геологическое моделирование. Это позволит оценить возможность картирования здесь отдельных локальных объектов поиска нефтегазовых ловушек тектонической природы.

Еще одна зона сложного сочетания $\Delta g$ и $\Delta T$ - протяженный фрагмент профиля почти 70 км ширины, в пределах которого можно говорить о согласованном в целом поведении кривых $\Delta g$ и $\Delta T$. В его центральной части в районе ПК $240-$ 250 зарегистрировано простое прямое сочетание 4 (максимумы) кривых $\Delta g$ и $\Delta T$ на общем «синклинальном» фоне (см. рис. 4). Скорее всего, весь этот створ представляет собой субвертикальную зону деструкции (СЗД), трассирующую центральной осевой разлом (щелевидную зону, рифт) древнего Пачелмского авлакогена.

Далее (см. рис. 4 аномалия 5) очевидно, что инверсному сочетанию минимум-максимум на ПК 270-310 отвечает, как уже говорилось, область внедрения на уровне фундамента пород с относительно пониженной плотностью и сопротивлением, но с повышенной намагниченностью (сиенитов). В целом весь этот участок характеризуется существенно иным характером соответствия кривых $\Delta g$ и $\Delta T$, нежели предыдущий. Здесь хорошего согласования информации полей $\Delta g$ и $\Delta T$ не просматривается, как на исходных кривых, так и на глубинных трансформациях (см. рис. 4).

Наконец, еще один выразительный и весьма своеобразный фрагмент из рассматриваемых сочетаний кривых $\Delta g$ и $\Delta T$ относится к интервалу ПК 320-376. В поле $\Delta g$ это участок сопряжения плавного и пологого минимума и максимума интенсивностью более 5 мГал, в поле $\Delta T$ такое сопряжение осложняет более глубокий минимум, приходящийся на ПК 344. На глубинных кривых рис. 4 западная часть этого интервала выражается в обоих полях минимумами, но далее к востоку от ПК 345 в гравитационном поле рисуется интенсивный максимум, а в $\Delta T$ - максимум сложной пилообразной формы. По разрезам (см. рис. 4) здесь контактируют вертикальные тела низкой и высокой намагниченности (плотности). Два последних участка относятся к «зоне влияния» Пугачевского свода. 


\section{Заключение}

Таким образом, проведенные исследования позволили существенно скорректировать прежние представления о строении и характере сопряжения крупнейших элементов тектоники Восточно-Европейской платформы: Воронежской антеклизы, Рязано-Саратовского мегапрогиба и Жигулевско-Пугачевского свода. Удалось также уточнить местоположение составляющих их структурных элементов (Аркадакского прогиба, Аткарского выступа и т.д.) и выявить своеобразие тектонического облика каждого из них. В итоге можно по-новому районировать территорию, через которую проложен региональный профиль, выделив в ее составе уже не три, а пять различных по своему строению участков, обозначенных на карте рис. 3 арабскими цифрами, расположенными к югу от линии профиля: 1) Воронежскую антеклизу, 2) западную склоновую часть Рязано-Саратовского мегапрогиба (Аркадакский прогиб), 3) центральную осевую часть мегапрогиба (Пачелмский авлакоген), 4) Самарский блок Жиулевско-Пугачевского свода, 5) западное окончание (Терешкинская вершина) Пугачевского свода.

Такое районирование определяется в первую очередь наличием четырех резких градиентных (разломных) зон северо-западного простирания и различным характером сочетаний потенциальных полей в пределах выделенных участков [7]. В целом на рассмотренной части территории Рязано-Саратовского прогиба по гравимагнитным материалам подтверждаются представления о формировании к палеозою структуры, унаследованно развивавшейся по Пачелмскому авлакогену, однако границы прогиба не совпадают с границами авлакогена. В процессе формирования Рязано-Саратовского прогиба на границе палеозоя и мезозоя по геолого-геофизическим данным [3] происходит активизация тектонических движений со сменой их знака. Начинается формирование новых структурных элементов, заложение инверсионных структур. Так, над Ртищевско-Баландинском грабеном в нижнем структурном этаже развиваются Ртищевский и Баландинский валы, а над Аткарским выступом - Аткарская впадина. Возникают и новые контрастные структуры, такие как Чембарско-Петровский грабен (зона дислокаций в районе осевой линии авлакогена). Имеющийся опыт поисков и разведки нефтега- зовых месторождений свидетельствует о наличии локальных структур (в частности, в области Аткарской и Сосновской впадин), но с низкими перспективами нефтегазоносности девонских отложений. Изучение ловушек в низах девона, судя по оценкам на Папановской, Глазуновской и других площадях, дало отрицательные результаты, равно как и оценка «молодых» структур преднеогенового формирования.

В плане лицензионной привлекательности можно выделить наименее изученные участки в центральной зоне Рязано-Саратовского прогиба (в области Ртищевско-Баландинских и Чембарско-Петровских дислокаций) и в пределах Самарского блока, где наблюдается наибольшая возмущенность геопотенциальных полей. Выполненные исследования свидетельствуют о несомненной полезности и необходимости проведения грави- и магнитометрических наблюдений при отработке региональных геофизических профилей.

\section{Библиографический список}

1. Создание государственной сети опорных геофизических профилей. Основные положения Федеральной программы развития минерально-сырьевой базы РФ на 1994-2000 годы // Геофизический вестн. Октябрь 1994. C. 4-8.

2. Липилин А.В., Никитин А.А., Черемисина Е.Н. Проблемы комплексной интерпретации геофизических данных по региональным профилям и пути их решения // Геофизика. 2002. № 4. C. 3-6.

3. Шебалдин В.П. Тектоника Саратовской области. Саратов, $2008.40 \mathrm{c}$.

4. Рыскин М.И., Лепилин В.М., Романов В.В. Геофизические основы тектонического районирования платформенных территорий // Геология нефти и газа. 1995. № 3. C. $15-20$.

5. Буш В.А., Бабаяни П.С., Блох Ю.И. и др. Новые данные по глубинному строению Прикаспийского нефтегазоносного бассейна и южной окраине Русской плиты // Геологические и технологические предпосылки расширения ресурсов углеводородного сырья в европейской части России / Под ред. Д.Л. Федорова. М., 2006. С. 58-65.

6. Андреев Б.А. Геофизические методы в региональной и структурной геологии. М., 1967. 324 с.

7. Рыскин М.И., Волкова Е.Н., Сокулина К.Б. и др. Комплексная интерпретация геофизических данных в зоне сопряжения Воронежской антеклизы с Рязано-Саратовским прогибом // Геофизика. 2010. № 4. С. 31-40. 